\title{
SUMBER PEMBIAYAAN DAN PRODUKSI BENIH KENTANG DI KECAMATAN KERTASARI KABUPATEN BANDUNG
}

\section{FUNDING SOURCES AND THE PRODUCTION OF POTATO SEEDS IN KERTASARI SUBDISTRICT BANDUNG DISTRICT}

\author{
Amelia Hendra*, Eliana Wulandari \\ Program Studi Agribisnis Fakultas Pertanian Universitas Padjadjaran \\ Jl. Raya Jatinangor Sumedang Km. 21 \\ *Email: ameliahendra66@yahoo.com \\ (Diterima 18-10-2019; Disetujui 18-11-2019)
}

\begin{abstract}
ABSTRAK
Kentang (Solanum tuberosum L.) merupakan salah satu komoditas hortikultura yang banyak dicari dan berharga cukup tinggi. Produksi kentang di Indonesia tergolong masih rendah apabila dibandingkan dengan produksi kentang di negara lain. Salah satu penghambat produksi kentang ialah penggunaan modal yang cukup tinggi dalam kegiatan produksi benih kentang. Kecamatan Kertasari merupakan salah satu wilayah produksi benih kentang di Jawa Barat, khususnya Kabupaten Bandung. Kendala permodalan membuat petani perlu mencari sumber pembiayaan yang dapat memenuhi kebutuhannya agar produksi benih kentang dapat tetap berjalan. Tidak sedikit petani yang mengandalkan sumber pembiayaan formal maupun non-formal sedangkan beberapa lainnya mampu memenuhi kebutuhan permodalan dengan biaya pribadi. Melalui penelitian ini, ingin diketahui sumber-sumber pembiayaan dan hasil produksi benih kentang yang dihasilkan petani di Kecamatan Kertasari Kabupaten Bandung. Penelitian ini menggunakan desain penelitian kuantitatif dengan pendekatan deskriptif. Alat analisis data yang digunakan adalah analisis deskriptif menggunakan tabulasi silang. Hasil penelitian menunjukkan bahwa petani yang memproduksi benih kentang di Kecamatan Kertasari Kabupaten Bandung dengan sumber pembiayaan dari bank komersial, kerabat atau tetangga, dan dana pribadi memperoleh hasil produksi lebih tinggi dibandingkan dengan petani yang tidak mempunyai pembiayaan dari sumber tersebut. Sedangkan petani yang mempunyai pembiayaan dari kelompok tani, pembeli, dan kios pertanian, memperoleh hasil produksi lebih tinggi dibandingkan dengan petani yang mempunyai pembiayaan dari sumber tersebut.
\end{abstract}

Kata kunci: benih kentang, sumber pembiayaan, hasil produksi

\begin{abstract}
Potato (Solanum tuberosum L.) is one of the sought-after horticultural commodities and has a high economic value. Potato production in Indonesia is still relatively low compared to potato production in other countries. One obstacle in producing potato is the use of sufficiently high capital in potato seed production activities. Kertasari Subdistrict is one of the areas of potato seed production in West Java, especially in Bandung District. Capital constraints have caused farmers have to look for sources of financing that can meet their needs in order to continuously produce potato seeds. Some farmers rely on formal and non-formal financing sources while some others are able to meet capital needs with personal costs. The purpose of this research is to identify funding sources and potato seeds produced by farmers in Kertasari Subdistrict, Bandung District. This research uses a quantitative research design using a descriptive approach. Data analysis tools used are descriptive analysis using cross tabulation analysis. The results showed that farmers who produced potato seeds in Kertasari Subdistrict, Bandung District with funding sources from commercial banks, relatives or neighbors, and private funds had higher production yields compared to farmers without funding from these sources. Whereas farmers without funding from farmer groups, buyers, and agricultural kiosks, had higher production yields compared to farmers who had funding from these sources.
\end{abstract}

Keywords: potato seeds, funding sources, production yield 


\section{PENDAHULUAN}

Kentang (Solanum tuberosum L.) merupakan salah satu komoditas hortikultura yang dapat dijadikan sebagai pengganti makanan pokok karena dalam 100 gram kentang terkandung karbohidrat yang cukup tinggi, yaitu 85,6 gram. Kentang dapat dikonsumsi dengan cara direbus atau dengan cara diolah, seperti keripik, French fries, perkedel, dan olahan lainnya. Kentang juga memiliki berbagai macam manfaat, diantaranya dapat mencegah penyakit sistem pencernaan karena memiliki kandungan serat yang tinggi, mengendalikan kadar gula darah pada penderita diabetes karena mengandung glukosa, digunakan dalam perawatan kulit, serta manfaat lainnya (Lianto, 2014). Berbagai manfaat dan jenis olahan yang dapat diperoleh dari kentang menjadikan kentang banyak dicari dan berharga cukup tinggi jika dibandingkan dengan komoditas lainnya.

Selama kurun waktu tujuh tahun (2011-2017), hasil produksi kentang di Indonesia berfluktuasi dengan kecenderungan peningkatan. Namun, hasil produksi kentang sejak tahun 2014 justru menunjukan tren penurunan. Hal tersebut mungkin disebabkan oleh berbagai tantangan pengembangan kentang di dataran tinggi, seperti bersaing dengan komoditas hortikultura lain dan konservasi lahan untuk peruntukan lain (Rogi dkk, 2016). Menurut data Kementerian Pertanian (2018), produktivitas kentang Indonesia pada tahun 2017 ialah sebesar 15,40 ton/ha. Nilai produktivitas tersebut masih tergolong rendah apabila dibandingkan dengan produktivitas kentang di negara produsen kentang lainnya di Asia. Produktivitas kentang di Thailand dan India mencapai 16,34 dan 22,30 ton/ha. Meskipun memiliki iklim yang hampir sama dengan kedua negara tersebut, produktivitas kentang Indonesia masih berada di bawah kedua negara tersebut (Jella dkk, 2017).

Produktivitas kentang dipengaruhi oleh beberapa faktor, seperti luas lahan, jumlah pupuk yang digunakan, dan biaya pestisida serta tingkat teknologi petani (Kasimin, 2013). Selain itu, Aulia dkk (2014) mengungkapkan bahwa penyebab rendahnya produktivitas kentang di Indonesia disebabkan oleh rendahnya kualitas dan kuantitas benih, teknik budidaya konvensional yang masih digunakan petani, terbatasnya daerah yang sesuai untuk budidaya kentang, serta serangan hama dan penyakit. Selain itu, modal yang cukup tinggi dan perencanaan yang baik dibutuhkan dalam kegiatan 
produksi benih kentang (Amrullah dkk, 2019).

Salah satu wilayah di Kabupaten Bandung yang memproduksi benih kentang adalah Kecamatan Kertasari. Kegiatan pelatihan produksi benih kentang telah diberikan oleh pemerintah dan Japan International Cooperation Agency (JICA) kepada sepuluh orang petani di Kecamatan Kertasari terhitung sejak tahun 1982. Terhitung kurang lebih empat kali pelatihan produksi benih kentang telah diterima oleh petani di Kecamatan Kertasari. Pasca pelatihan, petani pun mendapatkan pendidikan lapangan dan pendampingan dari Balai Pengawasan dan Sertifikasi Benih Tanaman Pangan dan Hortikultura (BPSBTPH) selama satu tahun. Program pelatihan tersebut bertujuan agar Kecamatan Kertasari mampu menjadi salah satu wilayah penghasil benih kentang di Kabupaten Bandung.

Namun, menurut pengakuan salah satu petani produsen benih kentang di Kecamatan Kertasari, terdapat kendala terkait permodalan yang menghambat aktivitas produksi benih kentang. Salah satunya adalah mahalnya biaya sertifikasi benih. Hasil benih yang akan disertifikasi oleh petani dibebankan biaya sebesar Rp 25 per kilogramnya untuk benih G2, jadi kalau "melabel" 10 ton petani sudah merasa keberatan. Apalagi jika mensertifikasi benih G0 dan G1 dimana biaya yang dibebankan masing-masing sebesar Rp 5.000 dan Rp 3.000 per knol (per benih kentang).

Kendala permodalan tersebut membuat petani harus mencari sumber pembiayaan yang dapat memenuhi kebutuhannya sehingga produksi benih kentang tetap berjalan. Tidak sedikit petani yang mengandalkan sumber pembiayaan formal maupun non formal sedangkan beberapa lainnya mampu memenuhi kebutuhan permodalan dengan biaya pribadi. Melalui penelitian ini, ingin diketahui sumber-sumber pembiayaan dan produksi benih kentang yang dihasilkan petani di Kecamatan Kertasari Kabupaten Bandung.

\section{METODE PENELITIAN}

Penelitian ini dilakukan di Kecamatan Kertasari Kabupaten Bandung. Pemilihan tempat penelitian didasari atas pertimbangan bahwa Kecamatan Kertasari merupakan salah satu sentra produksi kentang di Kabupaten Bandung dan juga merupakan salah satu wilayah penangkaran benih kentang yang masih terkendala terkait masalah 
permodalan. Penelitian berlangsung selama bulan Maret hingga Juni 2019.

Desain penelitian yang digunakan ialah desain penelitian kuantitatif dengan pendekatan deskriptif. Penelitian ini bertujuan untuk menganalisis pengaruh variabel sumber pembiayaan terhadap variabel hasil produksi benih kentang. Sumber pembiayaan dikategorikan menjadi beberapa jenis, diantaranya bank komersil, kelompok tani, pembeli, kios pertanian, kerabat atau tetangga, dan dana pribadi.

Data yang digunakan dalam penelitian ini merupakan data primer dan data sekunder yang dikumpulkan melalui beberapa metode pengumpulan data, diantaranya adalah observasi, wawancara, kuesioner, dan studi pustaka. Menurut Arikunto (2010), jika populasi jumlahnya kurang dari 100 orang maka seluruhnya dijadikan sampel, tetapi jika populasi lebih dari 100 orang maka sampel bisa diambil sebanyak 10-25 persen dari jumlah populasinya. Populasi petani penangkar benih kentang di Kecamatan Kertasari, Kabupaten Bandung adalah sebanyak 10 orang. Oleh karena itu seluruh populasi dijadikan responden dalam penelitian ini.

Pada penelitian ini, data diolah menggunakan metode analisis deskriptif untuk mengubah sekumpulan data menjadi bentuk yang lebih mudah dipahami (Istijanto, 2009) dan analisis tabulasi silang (cross-tab analysis). Analisis deskriptif pada penelitian ini dilakukan pada hasil data responden yang merupakan karakteristik responden seperti umur, pengalaman produksi benih kentang, luas lahan penangkaran benih kentang, dan hasil produksi benih kentang pada tahun 2018. Analisis tabulasi silang dilakukan pada variabel sumber pembiayaan terhadap variabel hasil produksi benih kentang.

\section{HASIL DAN PEMBAHASAN}

Hasil penyebaran kuesioner terhadap sepuluh orang petani yang memproduksi benih kentang di Kecamatan Kertasari Kabupaten Bandung, diperoleh informasi bahwa $100 \%$ responden berjenis kelamin lakilaki dengan umur rata-rata 51,4 tahun dimana umur tersebut tergolong dalam kelompok umur produktif. Rata-rata responden telah menjalankan kegiatan produksi benih kentang selama 9,4 tahun. Bahkan, terdapat dua responden (20\%) yang telah menjalankan kegiatan produksi benih kentang lebih dari 10 tahun yang tergolong sudah berpengalaman. (Soeharjo and Patong, 1999). Mayoritas 
petani menggunakan planlet sebagai benih penjenis dalam kegiatan produksi benih kentang sehingga diperlukan screen house dan lapangan dalam kegiatan produksinya. Rata-rata luas screen house dan lapangan yang dimiliki oleh petani ialah 0,11 dan 4,54 ha dengan rata-rata produksi benih kentang sebesar 8.980 $\mathrm{kg} /$ musim.

Hasil analisis cross-tab pada Tabel 1 menunjukan bahwa petani yang memproduksi benih kentang dengan sumber pembiayaan dari bank komersil memperoleh hasil produksi yang lebih tinggi dibandingkan dengan petani yang tidak memperoleh pembiayaan dari bank komersil. Terdapat beberapa jenis kredit yang dapat diperoleh petani, yaitu kredit komersial atau Kredit Usaha Rakyat
(KUR). Untuk memperoleh pembiayaan dari bank, petani perlu mengisi formulir pengajuan kredit dan melampirkan dokumen pendukung seperti fotokopi Kartu Tanda Penduduk (KTP) dari peminjam dan istri/suaminya, fotokopi sertifikat tanah, slip gaji, deposito, atau BPKB kendaraan bermotor (Wulandari dkk, 2017). Namun, petani selama ini kesulitan untuk mendapatkan pembiayaan dari bank komersial karena pengajuan kredit memerlukan agunan berupa lahan atau hasil produksi yang akan dipanen (Hasan, 1979 dalam Harahap dkk, 2019). Sulitnya akses petani terbukti dengan rendahnya persentase jumlah petani yang memperoleh pembiayaan dari bank komersial yaitu 10 persen.

Tabel 1. Analisis Cross-tab

\begin{tabular}{llr}
\hline \multicolumn{1}{c}{$\begin{array}{c}\text { Sumber } \\
\text { Pembiayaan }\end{array}$} & \multicolumn{1}{c}{ Indikator Pembiayaan } & Produksi (Kg) \\
\hline \multirow{2}{*}{ Bank } & Mendapatkan kredit dari bank & $8.755,556$ \\
\cline { 2 - 3 } Kelompok tani & Tidak mendapatkan kredit dari bank & $11.000,000$ \\
\cline { 2 - 3 } & Tidak mendapatkan bantuan input produksi dari kelompok tani & $9.422,222$ \\
\hline \multirow{2}{*}{ Pembeli } & Mendapatkan dana pinjaman untuk input produksi dari pembeli & $5.000,000$ \\
\cline { 2 - 3 } & Tidak mendapatkan dana pinjaman untuk input produksi dari & $10.571,430$ \\
\hline \multirow{2}{*}{ Kios pertanian } & Mendapatkan penangguhan pembayaran input & $5.266,667$ \\
\cline { 2 - 3 } & Tidak mendapatkan penangguhan pembayaran input & $10.166,670$ \\
\hline \multirow{2}{*}{ Kerabat/tetangga } & Mendapatkan pinjaman dari kerabat/tetangga & $7.200,000$ \\
\cline { 2 - 3 } & Tidak mendapatkan pinjaman dari kerabat/tetangga & $8.857,143$ \\
\hline \multirow{2}{*}{ Dana pribadi } & Pendanaan menggunakan dana pribadi & $7.266,667$ \\
\cline { 2 - 3 } & Pendanaan tidak menggunakan dana pribadi & $10.500,000$ \\
\hline
\end{tabular}

Petani di Kecamatan Kertasari yang memproduksi benih kentang dengan sumber pembiayaan dari kerabat atau tetangga dan dana pribadi masing-masing sejumlah $70 \%$ dan 60\%. Para petani tersebut memperoleh hasil produksi yang 
lebih tinggi dibandingkan dengan petani yang tidak mendapat pembiayaan dari sumber pembiayaan tersebut. Sedangkan hasil panen pada petani yang tidak mendapat pembiayaan dari kelompok tani, pembeli, dan kios pertanian justru lebih tinggi dari petani yang memperoleh pembiayaan dari sumber pembiayaan tersebut. Hal tersebut mungkin terjadi karena pembiayaan yang diberikan terbatas sehingga petani memberikan pupuk dengan jumlah yang kurang dari dosis anjuran pemerintah (Rangkuti, 2012). Selain itu, pola hubungan patron klien yang terjalin antara petani dan pembeli hasil pertanian merupakan hubungan yang kuat dan terjalin lama (Rustinsyah, 2011) sehingga petani tidak dapat terlepas dari hubungan tersebut.

\section{KESIMPULAN DAN SARAN}

Hasil penelitian menunjukkan bahwa petani yang memproduksi benih kentang di Kecamatan Kertasari Kabupaten Bandung dengan sumber pembiayaan dari bank komersial, kerabat atau tetangga, dan dana pribadi memperoleh hasil produksi lebih tinggi dari petani tanpa pembiayaan dari sumber tersebut. Sedangkan petani tanpa pembiayaan dari kelompok tani, pembeli, dan kios pertanian, memperoleh hasil produksi lebih tinggi dari petani dengan pembiayaan dari sumber tersebut.

Saran yang dapat diberikan berdasarkan hasil penelitian ini ialah perlu adanya pendampingan, baik dari penyuluh pertanian, akademisi, maupun pemerintah, terhadap petani terkait berbagai jenis sumber pembiayaan dan cara untuk mengaksesnya sehingga permodalan tidak lagi menjadi masalah yang menghambat kegiatan produksi benih kentang yang dilakukan oleh petani di Kecamatan Kertasari Kabupaten Bandung.

\section{DAFTAR PUSTAKA}

Amrullah, M. R., Sudarsono, \& Amarillis, S. (2019). Produksi dan Budidaya Umbi Bibit Kentang (Solanum tuberosum L.) di Pangalengan, Bandung, Jawa Barat. Buletin Agrohorti, 7(1), 93-99.

Arikunto, S. (2010). Prosedur Penelitian Suatu pendekatan Praktek. Jakarta: Rineka Cipta.

Aulia, A. L., Nawawi, M., \& Wardiyati, T. (2014). Uji Daya Hasil Tujuh Klon Tanaman Kentang (Solanum tuberosum L.). Jurnal Produksi Tanaman, 1(6), 514-521.

Harahap, L. K., Sihombing, L., \& Salmiah. (2019). Sikap Dan Perilaku Petani Pedesaan Dalam Mengambil Keputusan Memperoleh Kredit Usaha Tani Di Bank Konvensional. Jurnal Sosial Ekonomi Pertanian, 15(1), 96-103.

Istijanto. (2009). Aplikasi Praktis Riset Pemasaran. Jakarta: Gramedia Pustaka Utama.

Jella, E. R., Suryanto, A., \& Setyobudi, L. (2017). Dampak Aplikasi Mulsa dan 
Generasi Umbi Bibit (G2, G3, Lokal) pada Tanaman Kentang (Solanum tuberosum Linn). Buana Sains, 17(2), 153-166.

Kasimin, S. (2013). Keterkaitan Produk dan Pelaku dalam Pengembangan Agribisnis Hortikultura Unggulan di Provinsi Aceh. Jurnal Manajemen \& Agribisnis, 10(2), 117-127.

Kementerian Pertanian. (2018). Statistik Pertanian 2018. Jakarta: Kementerian Pertanian.

Lianto, M. I. (2014). Pembuatan Alat Pemotong Kentang Spiral. Universitas Lampung.

Rangkuti, S. (2012). Efektifitas Pendistribusian Pupuk Bersubsidi di Kabupaten Deli Serdang Studi Kasus di Kecamatan Hamparan Perak. Jurnal Administrasi Publik, 3(2), 287-318.
Rogi, J. E. X., Kembuan, H. S. G., \& Rombang, J. A. (2016). Laju Tumbuh Umbi Tanaman Kentang Varietas Granola dan Supejohn di Dataran Medium dengan Pemulsaan. Jurnal Hortikultura Indonesia, 7(2), 83-90.

Rustinsyah. (2011). Hubungan PatronKlien di Kalangan Petani Desa Kebonrejo. Jurnal Masyarakat, Kebudayaan Dan Politik, 24(2), 176-182.

Soeharjo, A., \& Patong, D. (1999). Sendi - Sendi Pokok Usahatani. Bogor: Institut Pertanian Bogor.

Wulandari, E., Meuwissen, M. P. M., Karmana, M. H., \& Lansink, A. G. J. M. O. (2017). Access to finance from different finance provider types: Farmer knowledge of the requirements. PLoS ONE, 12(9). 